Metodički obzori 6(2011)2

Original scientific article

UDK: 004.738.52:373.3]:37.064.1

Received: 21. 10. 2010.

\title{
SCHOOL WEBSITES: A POSSIBILITY OF COOPERATION WITH PARENTS?
}

\author{
Dejana Tavas, graduate teacher \\ Vladimir Nazor Elementary School, Rovinj (Croatia) \\ e-mail: dtavas@yahoo.com \\ Sanja Bilač, graduate teacher \\ Spinut Elementary School, Split (Croatia) \\ e-mail: $\underline{\text { sanja.bilac@gmail.com }}$
}

\begin{abstract}
In the last fifteen years in Croatia, as well as around the world, much research has been done dealing with the importance of cooperation between parents and school, and the obtained results show its importance for all the parties, and that partnership relation between school and parents produces numerous benefits. Besides customary ways of communication like individual talk and parent meetings, written messages, informal meetings, educational workshops, the involvement of parents in the educational process in the role of accessory etc., the most modern way of communicating with parents is via school websites, teacher's websites, e-mails, and SMS messages. The goal of the research was to examine if Croatian schools' websites had the content which would prompt the parents for frequent visits and enable pupils to acquire new knowledge. A long term goal was to persuade schools to a regular update of new materials which would result in quality cooperation between home and school, and persuade pupils to do research from their home and therefore increase the quality of learning. The research has randomly selected 25 elementary school websites from the county of Istria, and 25 websites from the county Split - Dalmatia. Collected data show that Croatia's elementary school websites are not a model neither for increasing the cooperation with parents nor laying the foundation towards a new culture of learning, and that there is no statistically significant variation in content between the two counties.
\end{abstract}

Key words: cooperation with parents, Internet, school websites, website content

\section{Parents and school cooperation}

The cooperation between parents and schools is extremely important and offers manifold benefits for all the participants in the education process. A partnership between parents and teachers establishes good relations since all partners introduce their competences in the child's education. The cooperation between parents and teachers, i.e. school, should be the best possible to achieve outstanding goals. Berger (1991) considers that models of parent involvement are approached more actively nowadays then it was in 
the 1960s when the responsibilities of parents and schools were considered distinct. Cooperation with parents is today considered one of the essential determinants of an efficient school in terms of general pedagogy, and research has shown that $22 \%$ of teachers consider the lack of parent involvement a serious problem (Ryan and Cooper, 2010). Such cooperation is only partially directed at prevention, i.e. solution of disciplinary problems, since its benefits are manifold, and are manifested in: better grades, increased regular attendance, more willingness to work at home, and development of more positive attitudes and behaviour. Parental involvement in school life has a positive effect on pupil's achievements and their motivation, and the partnership relation between parents and schools makes parents better informed of school affairs, gives them a more positive image in the eyes of the teachers, they contribute to a better functioning of the school, strengthen their self-confidence and assurance in helping their child at home, and they become participants, not mere observers of the education of their child. Teachers also gain from a partnership relation with parents since the parents become allies in solving problems; they become more motivated and satisfied with their job, receive more confidence from parents and have a better reputation in society.

These, and other benefits for all the participants in the education process are the result of a growing willingness and need of parent involvement in the school life. According to Walsh (2002) one way of achieving a successful bond between parents and school is a consistent and clear two-way communication.

Epstein (1995) lists three learning contexts for pupils: the family, school and the community, and lists 6 types of parent involvement. These are: parenting, communication, volunteering, learning at home, decision making and collaborating with community. However, all of these types of cooperation between parents and school presume direct communication, which at times, regardless of the parents' willingness, is impossible. Many parents work during planned school activities or meetings, and do not have the possibility to participate, especially in schools which work in a single shift. Today's way of life and both parents working prevent personal communication and a more active involvement of parents with schools.

\section{Contemporary ways of cooperation between parents and school}

One of the key features of humans is the ability to communicate. The exceptional ability of storing data and fast sharing of enormous amounts of information have revolutionized business as well as the everyday life of mankind. The access to information is unlimited, the sharing of ideas and thoughts free, the world's business and economy are being transformed. Significant are the changes in the approach to education. Fast communication is becoming a trend in shaping the future, and therefore revolutionary models of learning are more and more inherent (e.g. using interactive computer technology, fast learning...). Pupils are assuming responsibility for their life in a world in which "those who end their education have no future" (Dryden and Vos, 2001 p. 39). Stronger is the criticism of the educational system for its inertness in the process of change, and positive initiatives empowered by scientific research become the link for modernization and improvement of the school in the $21^{\text {st }}$ century. 
Technology has become a critical component of everyday life and an increase in the development and use of school websites over the last few years is evident (Hartshorne and ass. 2008). Research (Aronson 1995, Cameron and Lee 1997, ClemensBrower 1997, Cleverson 1999, Ramirez 2001) show that many teachers experiment with various technologies when communicating with parents (telephones in classrooms, voice mail, video technology, radio announcements, etc.) to improve cooperation. School websites provide parents with useful content such as educational tips, homework, emails or the school cafeteria menu, and expand the borders of communication between home and school to a 24 hours a day, 7 days a week contact. That allows parents whose daily timetable doesn't permit regular visits to the school and face-to-face interaction with their child or teacher to be more informed of what is happening at school. Internet becomes an excellent means of connecting home and school.

Swan (2008) believes that schools have a lot of information, and parents want to know more about academic achievements, extracurricular activities, parents' meeting schedule, information such as bus transport or lunch, and that it is important that school websites include accurate and useful information, not an exciting design or newest technological "ornaments".

Online research (Unal, 2008) shows that parents and teachers recognize the importance of school websites, although they do not agree completely on their content. While teachers suggest that links inside the school, classroom rules, teaching curriculum and standards, list of obligatory accessories, statistics of websites visitors and guest book should be essential to a school website, significant divergence $(\mathrm{p}<.05)$ was seen in parents, disagreeing on these elements. On the other hand, parents declare they would like to see online practical tests, academic advisory information, information about administrative issues and school direction, as well as teachers CVs. Eventually, teachers and parents agree that results of school sport competition and activities, educational philosophy, lesson plans, links outside the institution, online articles and newsletters, class photo albums and news, teachers' blogs, menus, examples of didactic cards, personal links and teachers' family information are not essential elements of schools' websites. It can be concluded that, regardless of many schools today having their own website, not all are important for the communication of parents and teachers. Past research has shown that the structure and content of school websites should be carefully planned and developed.

According to McKenzie, J. (1997) the best websites have four purposes: 1. introduce visitors to its mission, its character, its offering to children, its stance on new technologies; 2. offer an opportunity for the publishing of student works and parents education; 3. act as a mediator to a larger share of information, and 4. provide rich data locally collected on curriculum related topics (such as local history). Some school websites contain all four of these elements, but the majority is concentrated upon providing a quality service in two or three of these elements.

\section{Cooperation between parents and school in Croatia}

In the elementary education in Croatia, the following ways of cooperation with parents are prescribed (most often by the School Statute): parent meetings, individual communication with teachers and school assistants, and written messages to parents. The 
Primary and Secondary Education Act (Ministry of Education, Science and Technology, 2008) prescribes the formation of a Parents' Council which comprises one parent from every class, and the president of the Parent's Council is appointed a member of the School Committee. Practice has shown that these prescribed ways of cooperation do not satisfy the teachers or the parents. Parent participation is merely formal, without real possibility of influencing important decisions. Centralization and standardization of the curriculum do not allow schools enough space for adapting to the needs of the local community, parent meeting come down to mere information sharing where parents are usually passive recipients of information, and parents asked to participate in some kind of school activity are rare. A research conducted among parents of pupil of the $4^{\text {th }}$ and $7^{\text {th }}$ grade from all Croatian regions and their teachers (Marušić, 2007) shows that two thirds of parents believes that they have too little possibility of participating in decision making in schools, more than $90 \%$ of parents have never taken part in activities related to cooperation between family and school, three quarters of parents state that there are no lectures or workshops organized in schools, and a third of parents does not know if such workshops are organized. A substantial number of parents have shown interest in participating in various school activities, but the initiative is expected to come from teachers.

However, the practice in Croatian schools in recent years has shown cases of undertaking additional strategies for cooperation with parents. Many workshops are being held, parents are involved as assistants on projects, and in the communication between parents and school improvement has been made in following and assessing the pupils' progress as well as in the feedback information on the pupils' progress (increasingly common are the pupils' maps, as an example of systematic, authentic and development assessment of pupils' progress).

As far as electronic cooperation is concerned, Croatia is one step back. The project "Net u školi" - "Net in the school" was initiated in 2003 and all schools in Croatia have been equipped with ISDN terminals, with the aim to improve the process of learning by using Internet in teaching and pupils' research from home, and by laying the foundation for a new culture of learning based on openness to new knowledge, new media and technology. Today, all schools in Croatia have the possibility to set up a website, and the teachers to open email accounts.

In Croatia, websites of teachers are a rare appearance, but the projects "Školski infocentar" and "SMS informativka" have been initiated, enabling informing parents on success, absence and other school activities, via simple and to the majority accessible ways of communication (SMS, email, Internet and voicemail). A small number of schools have incorporated a web directory, updated monthly by class masters, which can be checked at any time by parents equipped with a special password. Although not the most important fact, it should not be ignored that according to the Central Bureau of Statistics in 2009 only $38 \%$ of households in Croatia had access to the Internet, which complicates communication via websites, and not all teachers are computer literate. Such cooperation has its advantages and disadvantages. 
Table 1 Advantages and disadvantages of cooperation via electronic media

\begin{tabular}{|l|l|}
\hline \multicolumn{1}{|c|}{ ADVANTAGES } & \multicolumn{1}{c|}{ DISADVANTAGES } \\
\hline Information on child received daily & Both parents and teachers must be \\
Fast information transmission & computer literate \\
Not limited by time or place & All participants (parents, teachers) must \\
Time saving for parents & have Internet access \\
Time saving for teachers when sending general & Additional work for teachers (regular \\
information & updating of data) \\
Parents come to school prepared, themes for & Rarer encounters among parents and \\
conversation are educational & teachers \\
& Lack of face-to-face communication \\
& Financial expense for parents when \\
& sending SMS messages \\
& Possible abuse (password) \\
\hline
\end{tabular}

\section{Research methodology}

\section{Aim of research}

The aim of the research was to examine whether the content of Croatian elementary schools websites encourages frequent parents' visits and allows pupils to acquire new knowledge. A long term goal is to encourage schools to post new materials regularly which would result in high-quality cooperation between home and school, along with encouraging students to research work from their homes, and therefore advancing the quality of learning.

\section{Problem}

The problem of this work is to determine the current purpose of Croatian elementary schools websites.

\section{Hypothesis}

H-1 Websites of Croatian elementary schools, with their contents, do not pose a model for a more intensive cooperation with parents or lay the foundations for a new culture of learning.

H-2 There is no statistically significant difference in content between the two counties in none of the eleven categories.

\section{Participants and procedure}

School websites are public documents and welcome the outer world into the school, as well as a link between pupils and teachers with external sources of information and a possibility of better cooperation with parents. The function of school 
websites is to make public the achievements of pupils, to allow parents insight into daily activities, and to inform parents and the larger community of future activities, as well as strengthening cooperation between school, home and the local community. The function of the schools' websites should not be a mere electronic version of a notice board, or a picture of a school that seldom changes its appearance.

The research was conducted by content analysis method, on a random selection of 50 elementary school websites in the counties of Istria and Split - Dalmatia (25 schools per county). The Internet school directory of "Portal za škole" was used. Since in Croatia a research has not been conducted on parents and the content the parents believed to be important and relevant, the authors were led by a research done by an online study in USA (Unal, 2008) and the elements selected by teachers and parents in that study. The following website content was analysed: curriculum, about the school (school history), web counters, house rules (classroom rules), timetable and information for parents, results of school competition, photo albums, online tests (study materials), teachers' CV, tips for parents and forum. The analysis was done at the beginning of December 2010, by the end of the first term, giving the schools enough time to update and enrich the websites. This research did not take into consideration the design of websites, since in the majority of cases it has been done using Carnet hosting services and offered similar links. Regarding the fact that most schools have the same browser, a school is considered to have a website if a private document or link has been updated.

\section{Results and discussion}

Table 2 Overall analysed content in percentage

\begin{tabular}{|l|c|c|c|c|}
\hline \multicolumn{1}{|c|}{ CONTENT } & \multicolumn{4}{|c|}{ BOTH COUNTIES } \\
\hline & yes & percentage & no & percentage \\
\hline Curriculum & 41 & $82 \%$ & 9 & $18 \%$ \\
\hline Website counter & 8 & $16 \%$ & 42 & $84 \%$ \\
\hline House rules & 10 & $20 \%$ & 40 & $80 \%$ \\
\hline $\begin{array}{l}\text { Parents' } \\
\text { information }\end{array}$ & 28 & $56 \%$ & 22 & $44 \%$ \\
\hline $\begin{array}{l}\text { Results of school } \\
\text { competitions }\end{array}$ & 23 & $46 \%$ & 27 & $54 \%$ \\
\hline Photo album & 43 & $86 \%$ & 7 & $14 \%$ \\
\hline $\begin{array}{l}\text { Online tests } \\
\text { (study material) }\end{array}$ & 17 & $34 \%$ & 33 & $66 \%$ \\
\hline Teachers' CV & 2 & $4 \%$ & 48 & $96 \%$ \\
\hline Tips for parents & 18 & $36 \%$ & 32 & $64 \%$ \\
\hline Forum & 12 & $24 \%$ & 38 & $76 \%$ \\
\hline $\begin{array}{l}\text { About the school } \\
\text { (school history) }\end{array}$ & 50 & $100 \%$ & 0 & $0 \%$ \\
\hline
\end{tabular}

For table 2 it is evident that all schools have information about the school on the website, i.e. about its history (100\%), the majority has school photo alums (86\%) and the curriculum (82\%). More than half the schools $(56 \%)$ have the timetable for parents' 
information, and less then half $(46 \%)$ have sport achievements of their pupils. The fewest schools publish teachers' CVs (4\%) and website counters. Study materials and tips for parents are present on just above a third the websites $(34 \%, 36 \%)$.

It is visible from Chart 1 that results do not vary much between counties. The most discrepancy is shown in sports' achievements (Istria 72\%, Split - Dalmatia 20\%), and a $20 \%$ discrepancy is present in categories photo album and study material. Other discrepancies are smaller than $20 \%$. The $2^{\text {nd }}$ hypothesis was tested with the chi-square test. The hypothesis is considered valid in case that the probability of error is less than $5 \%$, considering that there is a statistically significant link between the analysed pair of variables.

Chart 1 Content according to county

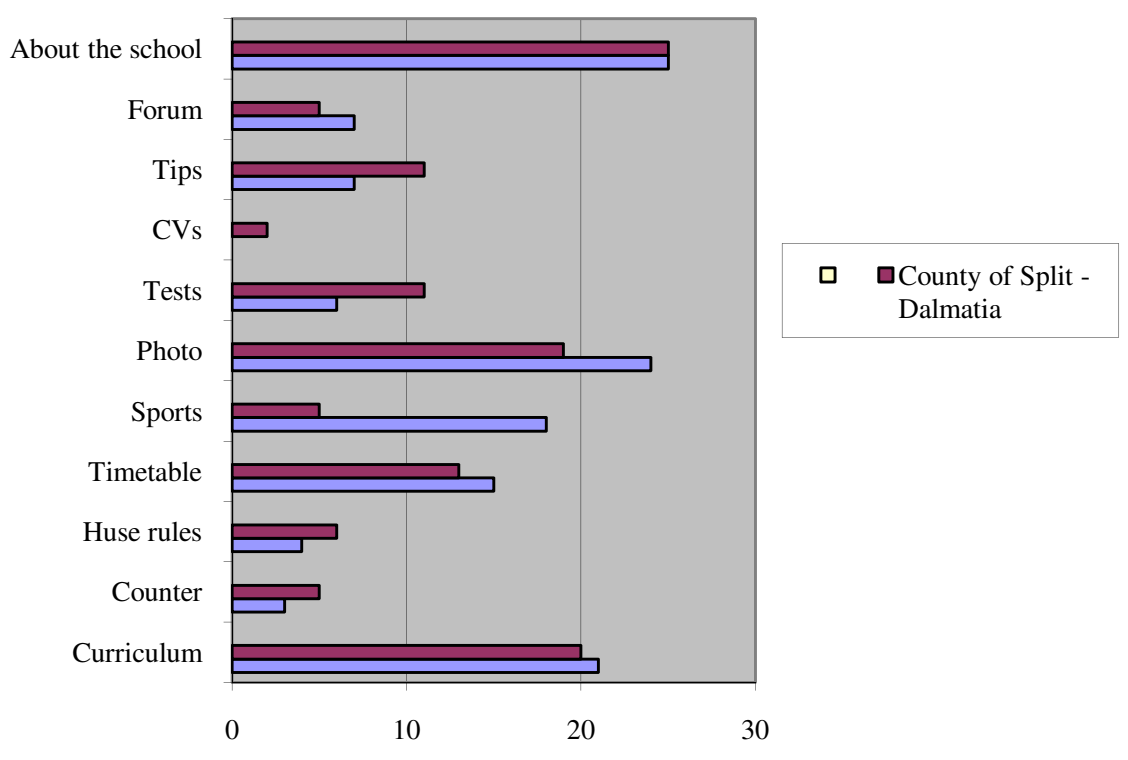

Table 3 Relations between counties

\begin{tabular}{|c|c|c|c|c|c|c|c|c|c|c|}
\hline & 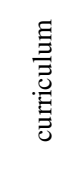 & $\begin{array}{l}\text { ñ } \\
\stackrel{0}{0} \\
\overline{0} \\
0 \\
0 \\
0 \\
\vdots\end{array}$ & 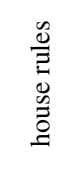 & 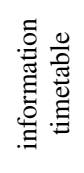 & 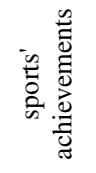 & 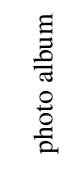 & 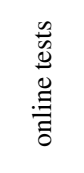 & 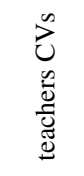 & 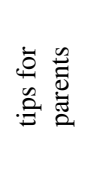 & 志 \\
\hline 2 & 0.024 & 0.149 & 0.125 & 0.081 & 11.594 & 2.658 & 1.471 & 0.521 & 0.781 & 0.110 \\
\hline df & 1 & 1 & 1 & 1 & 1 & 1 & 1 & 1 & 1 & 1 \\
\hline $\mathrm{p}$ & 0.877 & 0.480 & 0.527 & 0.705 & 0.007 & 0.446 & 0.225 & 0.157 & 0.346 & 0.564 \\
\hline
\end{tabular}


It is not difficult to notice that a significant discrepancy is present only in sports' achievement, whereas in other elements it does not exist, which confirms the stated hypothesis. It can be concluded that there are no differences between the content in the two counties.

The website content can be divided into two categories: content intended for parents and pupils (curriculum, timetable for parents' information, teachers' CVs, tips for parents, forum, online tests and study material, house rules) and content for promoting school activities and achievements (sports' achievements, photo albums, about the school, web counters).

Table 4 Analysis according to purpose

\begin{tabular}{|l|c|c|c|c|}
\hline CONTENT & \multicolumn{4}{|c|}{ BOTH COUNTIES } \\
\hline $\begin{array}{l}\text { INTENDEED FOR PARENTS } \\
\text { AND PUPILS }\end{array}$ & yes & percentage & no & percentage \\
\hline Online tests (study material) & 17 & $34 \%$ & 33 & $66 \%$ \\
\hline Curriculum & 41 & $82 \%$ & 9 & $18 \%$ \\
\hline Tips for parents & 18 & $36 \%$ & 32 & $64 \%$ \\
\hline House rules & 10 & $20 \%$ & 40 & $80 \%$ \\
\hline Parents' information timetable & 28 & $56 \%$ & 22 & $44 \%$ \\
\hline Forum & 12 & $24 \%$ & 38 & $76 \%$ \\
\hline Teachers' CV & 2 & $4 \%$ & 48 & $96 \%$ \\
\hline $\begin{array}{l}\text { PROMOTION OF SCHOOL } \\
\text { ACTIVITIES AND } \\
\text { ACHIEVEMENTS }\end{array}$ & yes & percentage & no & percentage \\
\hline Sports' achievements & 23 & $46 \%$ & 27 & $54 \%$ \\
\hline Photo album & 43 & $86 \%$ & 7 & $14 \%$ \\
\hline Web counters & 8 & $16 \%$ & 42 & $84 \%$ \\
\hline About the school & 50 & $100 \%$ & 0 & $0 \%$ \\
\hline
\end{tabular}

Among the content intended for parents and pupils, which would allow pupils to acquire new knowledge and encourage parents to visit regularly, schools offer in high percentage (82\%) the curriculum, which is a legal obligation (public notice), and just over half the schools $(56 \%)$ offer the timetable for parents' information. About one third of schools $(34 \%, 36 \%)$ publish on its websites study materials and tips for parents, and only $24 \%$ have an active forum for exchanging opinions, although these forums have an insignificant number of open themes, none of which were opened by parents. Study materials are most often online tests with a link from the website, and tips for parents are texts compiled by schools assistants. Considering the lack of assistants in schools, this may be the cause for a small percentage of these materials. Some schools under the section tips for parents have links to interesting Internet articles.

Categories intended for the promotion of school achievements and activities have more contents, every school has a page dedicated to school history, $86 \%$ update the photo album section, and less then half the schools (46\%) publish sports' achievements of the pupils. The photo albums offer pictures from school trips, out-of-primary teaching, school events, etc. Justifying such a large number of pictures is debatable, since none of the published materials are protected by password but available to 
everybody; the question arises if the schools have the parents' permission. Only $16 \%$ of schools pay attention to visits, which could be a significant information showing the number of parents and pupils visiting the website.

The mentioned data show that schools consider relevant to the promotion of school activities and success, the history of the school and the time allowed for parents to obtain information, but advice for parents and school materials, along with exchanging opinions, are not a priority. Schools consider the teachers' CVs, parents' meeting announcements or the school cafeteria menu to be of no relevance to parents. These facts point to the fact that school websites in Croatia are more online noticeboards, than a real possibility for communication.

\section{Conclusion}

Over the last decade cooperation with parents in Croatia has been improving; however, in our schools traditional forms of cooperation with parents still prevail. Although in the world there are specialized radio and TV channels, magazines and Internet sites for exchanging experiences (Mendel, 1998), such practice has not come into being in Croatia. However, over the last couple of years cooperation via websites, emails and short text messages has become more frequent. Summarising its advantages and disadvantages, and considering today's lifestyle, this way of cooperation should be intensified in our schools. Contemporary ways of communication can additionally improve the communication between parents and school, but just as one more way, alongside other ways. Consequently, although the modern age presupposes the use of modern technologies, no technology should replace face-to-face communication between parents and teachers, and the responsibility for a good cooperation still lies on the school.

The research demonstrates the possibilities of communication between family and school by using modern technology. Elements of school websites are shown, as well as ways of planning the content of a website. We consider this research important for informing teachers and school management of the possibilities of modern communication between families and school. A school website allows for the possibility of establishing fast communication; however its mere existence does not guarantee pupils acquiring new knowledge and a quality relation between the family and school. It can be a good example for the school management in creating the school curriculum as a segment allowing for a fast exchange of information with parents. Unfortunately, the educational system in Croatia is traditional and inert, unsuitable for the times and contemporary professions. It does not satisfy the need of the individual, and traditional teaching by using a minimum of technology and information is utterly un-motivational for the student as well as for the family. The results of this research show that school websites in Croatia don't fulfil their purpose: presenting pupils' achievements, allowing the parents insight into everyday activities, informing the parents and the wider community on future activities, and strengthening the cooperation between school, home and the local community. Although the purpose of school websites should not be merely an electronic version of the notice board and an image of the school that rarely changes 
its appearance, the current condition of the Croatian school websites, in the analysed counties, shows just that, confirming therefore the initial hypothesis.

Future research should inquire into the stance of parents in Croatia on what content they consider important, thus receiving relevant data which could later be used by teachers for creating their websites.

\section{References}

Berger, E. H. (1991), Parent Involvement: Yesterday and Today. The Elementary School Journal, 91 (3): 209-219.

Dryden, G. i Vos, J. (2001), Revolucija u učenju. Zagreb: Educa.

Epstein, J.L. (1995), School/family/community Partnerships: Caring for the Children We Share. Phi Delta Kappan: 76. http://nhs.needham.k12.ma.us/pages/stressr/Docs/Website\% 20Articles/Parents/Epstein\%20-\%20Parents.doc (15.11.2010.)

Epstein, J.L. i Sheldon, S. B. (2006), Moving Forward: Ideas for Research on School, Family, and Community Partnerships. http://www.csos.jhu.edu/p2000/pdf/Literature\%20 Review\%20\%20Epstein\%20and\%20Sheldon\%2006.pdf (15.11.2010.)

Graham- Clay, S. (2005), Communicating with Parents: Strategies for Teachers. School Community Journal, 16 (1): 117-129.

Hartshorne, R., Friedman, A., Algozzine, B., i Kaur, D. (2008). Analysis of Elementary School Web Sites. Educational Technology \& Society, 11 (1): 291-303.

Hitrec, G.(ur.) (2006). Škola otvorena roditeljima. Zagreb: Udruga roditelja Korak po korak.

Marušić, I. (2007), Škola otvorena roditeljima - rezultati istraživanja. Dijete Škola Obitelj, 20: $2-6$.

Mendel, M. (1998), 'Parents at School' programme as a perspective of partnership's orientation increase in Poland. http://www.ernape.net/articles/1999/mendel99.pdf (15.11.2010.)

Ryan, K, Cooper, J. M. (2010), Those Who Can Teach. Wadsworth Cengage Learning: Boston.http://books.google.hr/books?id=rqmdR6Xrgq8C\&printsec=frontcover\&source=gbs_ge_summ ary_r\&cad $=0 \# \mathrm{v}=$ onepage $\& \mathrm{q} \& \mathrm{f}=$ false $(15.11 .2010$.)

Swann, P. (2006). Got Web? Investing in a District Website. [Electronic Version]. TheSchool Administrator http://www.aasa.org/publications/saarticledetail.cfm?ItemNumber=6068 (15.11.2010.)

Unal, Z. (2008), Going The Extra Step For Parental Involvement: Connecting Family And School With The Power Of Teacher Websites. Journal of College Teaching \& Learning, 5 (6): 43-50. http://www.cluteinstitute-onlinejournals.com/PDFs/996.pdf (15.11.2010.)

Vizek Vidović, V. i sur. (2003), Psihologija obrazovanja. Zagreb: IEP.

Walsh, K.B. (2002), Kurikulum za prvi razred osnovne škole: stvaranje razreda usmjerenog na dijete. Zagreb: Matica d.o.o.

Zarevski, P. ur. (2003), Učitelji za učitelje primjeri provedbe načela Aktivne/efikasne škole. Zagreb: IEP.

Zakon o osnovnoškolskom i srednjem obrazovanju (2008), MZOŠ.

http://www.skole.hr/skole/popis (15.11.2010.) 
Metodički obzori 6(2011)2

Izvorni znanstveni rad

UDK: 004.738.52:373.3]:37.064.1

Primljeno: 21. 10. 2010.

\title{
ŠKOLSKE WEB STRANICE: MOGUĆNOST SURADNJE S RODITELJIMA?
}

\author{
Dejana Tavas, dipl. učiteljica \\ Osnovna škola Vladimira Nazora Rovinj (Croatia) \\ e-mail: dtavas@yahoo.com \\ Sanja Bilač, dipl. učiteljica \\ Osnlovna škola Spinut Split (Croatia) \\ e-mail: sanja.bilac@gmail.com
}

\begin{abstract}
S a žetak
Posljednjih petnaestak godina u svjetskoj i hrvatskoj obrazovnoj praksi provedena su brojna istraživanja o važnosti suradnje roditelja sa školom a dobiveni rezultati pokazuju da je ona iznimno važna za sve sudionike te da partnerski odnos škole i roditelja donosi svima višestruke koristi. Osim uobičajenih načina komuniciranja putem individualnih razgovora i roditeljskih sastanaka, pisanih poruka, neformalnih sastanaka, edukativnih radionica, uključivanjem roditelja u nastavni proces u ulozi pomagača i sl., najsuvremeniji načini komunikacije s roditeljima su web stranice škola, web mjesta učitelja, e-mail i SMS poruke. Cilj istraživanja bio je ispitati imaju li web stranice hrvatskih osnovnih škola sadržaje koji će potaknuti roditelje na česte posjete i omogućiti učenicima stjecanje novih znanja. Dugoročni je cilj potaknuti škole na redovito postavljanje novih sadržaja koji će rezultirati kvalitetnom suradnjom doma i škole te poticati učenike na istraživački rad iz svojih domova i time unaprjeđivati kvalitetu učenja. Istraživanje je obuhvatilo po 25 web stranica osnovnih škola iz Istarske i Splitsko-dalmatinske županije odabranih slučajnim izborom. Dobiveni rezultati pokazuju da web stranice hrvatskih osnovnih škola svojim sadržajima nisu model za intenziviranje suradnje s roditeljima te postavljanje temelja novoj kulturi učenja i da ne postoji statistički značajna razlika u sadržajima među dvjema županijama.
\end{abstract}

Ključne riječi: suradnja s roditeljima, načini suradnje roditelja $i$ škole, suvremeni oblici suradnje, sadržaji školskih web stranica 